\title{
UNIVERSITETO STUDENTŲ FIZINIO AKTYVUMO MOTYVACIJOS VEIKSNIAI: TEORINIAI POŽIŪRIAI
}

\author{
Donatas Gužauskas ${ }^{1}$, Inga Mikutavičien $\dot{e}^{2}$ \\ ${ }^{1}$ Kauno kolegija, 'Lietuvos sporto universitetas, \\ ${ }^{2}$ Vytauto Didžiojo universitetas
}

Raktažodžiai: motyvacija, fizinis aktyvumas, fizinio aktyvumo veiksniai.

\begin{abstract}
Santrauka
Straipsnyje nagrinejjami studentų fizinio aktyvumo sąlygų teoriniai aspektai. Motyvacija fiziniam aktyvumui nagrinejama iš tokių teorinių perspektyvų kaip socialinè kognityvine teorija, Penderio sveikatos skatinimo modelis, asmeninio veiksmingumo ir asmeninių schemų teorija, ekologinis modelis ir socialinis ekologinis modelis, planuojamo elgesio teorija, apsisprendimo teorija. Apibendrinus buvo išskirtos penkios, darančios įtaką studentų fiziniam aktyvumui veiksnių grupès: demografiniai ir biologiniai veiksniai; psichologiniai, kognityviniai ir emociniai veiksniai; elgesio atributai ir ịgūdžių veiksniai; socialiniai ir kultūrinai faktoriai; fiziniai aplinkos veiksniai, ypatingą dèmesị atkreipiant ị universiteto aplinką, suteikiamas fizinio aktyvumo galimybes, studijų turini, pasikeitusias studentų gyvenimo aplinkybes.
\end{abstract}

\section{Ivadas}

Daugelis tyrimų atskleidžia, jog fizinio aktyvumo stygius yra daugelio ligų rizikos veiksnys $[6,26,28]$. Remiantis PSO duomenimis, nepakankamas fizinis aktyvumas yra ketvirtasis pagrindinis mirtingumo rizikos veiksnys, taip pat susijęs su didesne koronarinès širdies ligos rizika, apskaičiuota, kad $7 \%$ fiziškai neaktyvių žmonių serga 2 tipo cukriniu diabetu, $10 \%$ krūties ir gaubtinès žarnos vėžiu [28]. F. Booth ir kt. [6] pabrèžia, jog mažas fizinis aktyvumas susijęs net su 35 lètinių ligų, tokių kaip metabolinis sindromas, hipertenzija, osteoporozė, giliųjų venų trombozè, reumatoidinis artritas, policystinių kiaušidžių sindromas ir kt. rizika. Nežiūrint $\mathfrak{i}$ ịspejjimus apie pasyvaus gyvenimo būdo keliamą riziką sveikatai, vis dèlto didelè dalis suaugusiujų Vakarų kultūrose yra fiziškai neaktyvūs [21,45,49].

Didelę dali jaunimo sudaro studentai. İvairių šalių at- liktuose tyrimuose aiškiai atskleidžiama per mažo studentų fizinio aktyvumo problema $[5,37,46,51]$. Studentų populiacija pasižymi tam tikru specifiškumu - prasideda naujas gyvenimo etapas, padidejja nepriklausomybé nuo tèvų, keičiasi gyvenama vieta,draugų ratas, pasikeitusios aplinkybès reikalauja naujų laiko planavimo igūdžių, atsakomybès, keičiasi dienotvarkè, didèja protinio darbo krūvis, didejja fiziškai pasyvaus laiko trukmè, praleidžiama prie kompiuterio, studijose, vykdant užduotis. Pasikeitusi aplinka gali paskatinti rizikingos elgsenos formavimąsi, kaip antai alkoholio, narkotinių medžiagų vartojimas, mitybos ịpročių pasikeitimas ir fizinio aktyvumo sumažèjimas $[7,19,53]$.

J. Irwin [23], apibendrinusi 27 pasaulio šalyse vykdytus studentų fizinio aktyvumo tyrimus, pažymi, jog tirtose šalyse nuo 30 iki 60 proc. studentų fizinis aktyvumas neatitiko rekomenduojamų normų ir skyrèsi priklausomai nuo šalies. M. Hagger ir N. Chatzisarantis [20] teigia, jog perspektyviausias požiūris, padèsiantis suprasti, kodèl jaunimas nedalyvauja fizinèje veikloje, yra susitelkti ị motyvaciją kaip pagrindinị veiksni, sąlygojantį atitinkamą elgesį ir jo palaikymą [4].

Nors tyrimų šioje srityje atliekama nemažai, trūksta sisteminio, integruoto požiūrio ị fizinio aktyvumo sąlygas, tyrimuose atspindimas vienas ar keletas fizini aktyvumo aspektų. Todèl, siekiant padidinti studentų fizinio aktyvumo lygi, pirmiausia reikia suprasti fizinio aktyvumo reiškinị bei jo komponentus apžvelgiant ịvairias teorines perspektyvas. Tyrimo problema formuluojama klausimu: kokie veiksniai turi itakos studentų fiziniam aktyvumui?

Šio straipsnio tikslas - atskleisti studentų fizinị aktyvumą sąlygojančius veiksnius ir pagrịsti jų sistemą iš įvairių teorinių požiūrių perspektyvos.

\section{Tyrimo objektas ir metodai}

Tyrimo objektas - studentų fizinio aktyvumo veiksniai. Šaltinių, analizuojančių fizinio aktyvumo teorijas ir požiūrius bei studentų fizinio aktyvumo veiksnius, ieškota duomenų bazèse „Pubmed“, „EBSCO“, „Schoolar Google“, 
Lietuvos sveikatos mokslų universiteto elektroniniame kataloge bei žurnalų „Sveikatos mokslai“ ir „Visuomenès sveikata“" archyvuose. Paieškai naudoti raktinių žodžių deriniai: ,physical activity" (liet. fizinis aktyvumas), ,students“ (liet. studentai), ,motivation“ (liet. motyvacija), ,theory“ (liet. teorija), ,, motivation factors “ (liet. motyvacijos veiksniai). Moksliniai straipsniai atrinkti atsižvelgiant ị šiuos kriterijus: 1) analizuojamos fizini aktyvumą aiškinančios teorijos ir požiūriai; 2) atlikti tyrimai grindžiami atitinkamomis fizinị aktyvumą aiškinančiomis teorinėmis nuostatomis ir modeliais; 3) pristatomi kiekybinio tyrimo rezultatai.

Pagrindinès jaunimo fizinio aktyvumo tyrimų kryptys ir teoriniai požiūriai. Itvairios studijos rodo, jog fizinis aktyvumas yra sudettingas, komplekso veiksnių sąlygotas elgesys. Todèl multiteorinè perspektyva leistu giliau ir išsamiau paaiškinti fizinio aktyvumo reiškinị bei ji sąlygojančias priežastis. Keletoje tyrimų kaip konceptualus pagrindas buvo panaudota A. Banduros socialinè-kognityvinè teorija (Social-Cognitive Theory), ịtraukianti asmeninius, elgsenos ir socialinès aplinkos kintamuosius [16,36,40]. Joje teigiama, jog žmonès mokosi vieni iš kitų per socialines sąveikas, patirtis bei veikiami aplinkos. Žmonès naudoja ịvairius simbolinius ir savireguliacinius procesus, nes jie skatina atsakingumo jausmo ugdymąsi. Pagrindiniai motyvaciniai procesai yra tikslai bei savarankiškas progreso vertinimas, vertybès, socialiniai palyginimai bei savarankiškumas. Žmonès nusistato tikslus ir vertina progresą. Progreso suvokimas išlaiko savarankiškumą. Žmonès elgiasi pagal savo vertybes ir siekia norimų rezultatų, o socialinis palyginimas su kitais asmenimis suteikia daugiau informacijos apie jų mokymosi bei tikslų iggyvendinimo pasiekimus. Savarankiškumas yra ypač svarbus motyvacijai ir lemia pasirinkimus, pastangas, atkaklumą bei laimèjimus [44]. Ypač svarbus yra aplinkos palaikymas, socialinio tinklo funkcionalumas.

A. Ammouri ir kt.[3], M. Chang [10], S. SherrickEscamilla [47], T. Wu ir N. Pender [54], M. Khodaveisi [25] jaunimo fizinio aktyvumo tyrimams pasirinko Penderio sveikatos skatinimo modeli (Pender's Health Promotion Model (HPM), kuris integruoja biologinius, psichologinius,socialinius ir aplinkos aspektus bei elgesi, kuris gali būti naudojamas jaunimo fiziniam aktyvumui paaiškinti. Tai yra vienas iš plačiai naudojamų modelių, skirtų planuoti ir keisti žalingą elgesị ir skatinti sveiką gyvenseną. Skirtingi tyrimai parodè šio modelio efektyvumą, siekiant kontroliuoti netinkamą elgseną $[38,39]$. Sveikatos skatinimo modelis remiasi socialine pažinimo teorija, pagal kurią kognityvinio suvokimo veiksniai (suvokiama nauda, kliūtys ir savęs veiksmingumas) turi įtakos formuotis sveikatą skatinančiam elgesiui, taip pat ir didesniam fiziniam aktyvumui. Manoma, kad modifikuoti veiksniai (demografi- niai ypatumai, tarpasmeniniai veiksniai ir elgesio veiksniai) sąveikauja tarpusavyje, siekiant paveikti kognityvinius suvokimo procesus. Pendero modelis orientuojasi ị tris sritis: individualias savybes ir patirti, elgesio suvokimą ir įtaką bei elgesio rezultatus. Teorija pažymi, kad kiekvienas žmogus turi unikalias asmenines savybes ir patirtị, kuri daro ịtaką tolesniems veiksmams. Sveikatos skatinimo elgesys yra norimas elgesio rezultatas, todèl jis yra sveikatos propagavimo modelio galutinis taškas. Asmeniniai veiksniai priskiriami prie biologinio, psichologinio ir sociokultūrinio pobūdžio veiksnių. Šie veiksniai numato tam tikrą elgesị ir formuojasi pagal numatomo elgesio pobūdį. Biologiniai asmeniniai veiksniai apima kintamuosius, tokius kaip amžiaus lyties kūno masès indeksas, pubertacijos būsena, aerobinis pajègumas, jèga, judrumas ar balansas. Psichologiniai asmeniniai veiksniai yra kintamieji, tokie kaip savęs vertinimas, savęs motyvacija, asmeninè kompetencija, suvokiama sveikatos būklè ir sveikatos apibrěžimas. Socialiniai ir kultūriniai asmeniniai veiksniai apima kintamuosius, tokius kaip rasès etniškumas, išsilavinimas ir socialinis bei ekonominis statusas [39].

M. Pis [41] savo tyrimą grindè asmeninio veiksmingumo ir asmenybinès schemos teorija (Self-Efficacy and Self-Schema Theory), kuri rodo, kad asmeninis efektyvumas daro pagrindinę ịtaką elgesiui. Asmeninio veiksmingumo suvokimas rodo, ar asmuo tiki, jog gali atlikti konkretų veiksmą ar elgtis pagal konkrečias apibrežtas normas [41]. Asmenybinès schemos teorija susijusi su patyrimais, ịsitikinimais ir idejomis apie save. Šie įsitikinimai paprastai naudojami gaunant ir apdorojant informaciją, ypač tą, kuri asmeniui yra svarbi. Schemos - tai labai stabilūs, ilgalaikiai elgesio modeliai ir įsitikinimai apie save bei aplinką. Schemų žmogus gali sąmoningai nesuvokti, tačiau kai tam tikri gyvenimo ìvykiai suaktyvina schemas, žmonių jausmai ir mąstymas yra stipriai jų veikiami: būtent turimos schemos nulemia, kaip žmogus jaučiasi, ką mąsto, kaip elgiasi tam tikrose situacijose. Dabartiniai tyrimai rodo, kaip sportuojančiujų bei nesportuojančiujų i veiklą orientuotos schemos turejjimas ir jokių schemų neturèjimas apskritai keitè savarankiško fizinio aktyvumo ypatumus, ar skyrèsi jų mintys bei emocijos fizinio aktyvumo atžvilgiu. Rezultatai atskleidè, kad sporto schemos turejimas didino fizinio aktyvumo dažnį, atliekamų pratimų skaičių, taip pat didejo tikimybe, kad asmuo sportavo ir praejusị semestrą. Sporto schema besinaudojantys asmenys buvo labiau susidomėję ir jautėsi ịsipareigoję sportuoti ateityje, planavo užsiimti fizine veikla reguliariai, žinojo motyvacijos būdus, kaip save paskatinti sportuoti dienomis, kai sportuoti nesinorejo [24].

M. Humbertas ir kt. [22] naudojo ekologinį modeli (Ecological Model) nustatyti veiksnius, turinčius įtakos fizinio 
aktyvumo lygiui tarp jaunimo, itraukiant individualius, socialinius ir aplinkos veiksnius. Ekologinis modelis kilo iš biologijos mokslų ir remiasi organizmo ir aplinkos tarpusavio sąveika. Pradejjus taikyti šị modelị elgesio bei visuomenès sveikatos mokslų srityse, pagrindinis demesys buvo kreipiamas į individo sąveikos su fizine ir sociokultūrine aplinka prigimti [50]. Pagrindinis ekologinio modelio skirtumas nuo kitų plačiai naudojamų elgesio teorijų, kurios koncentruojasi ties individualiomis charakteristikomis, ịgūdžiais ir artimosios socialinès aplinkos poveikiu (šeimos, draugu), yra tas, jog jis ịtraukia ir platesnị kontekstą - bendruomenès, organizacijos ar politinę aplinką [18]. Socialinis ekologinis požiūris (Social Ecological Model) pabrèžia, kad sveikatos skatinimas turètų būti orientuotas ne tik ị individualius elgesio veiksnius, bet ir į daugialypius veiksnius, turinčius įtakos konkrečiam elgesiui. Taigi socialinis ekologinis modelis yra orientuotas ị individų ir socialinès, fizinès, politinès ir globalios aplinkos veiksnius ir jų tarpusavio sąsajas [34,50]. Šis modelis yra svarbus daugelio lygmenų veiksnių, susijusių su fiziniu aktyvumu, nagrinejjimui ir padeda atpažinti individualias galimybes (pvz., lyties, įsitikinimų ir požiūrių), elgesio (pasyvus ir aktyvus laikas) bei socialinės aplinkos (řeimos, mokytojų, bendraamžių) ir fizinès aplinkos (pvz., fizinio aktyvumo ịranga ir ịrenginiai) veiksnius, kurie gali turèti ịtakos gebejjimui būti pakankamai fiziškai aktyviems $[32,42]$.

G. De Bruijn ir kt. [12] jaunimo fizinį aktyvumą tyrinejo remiantis planuojamo elgesio teorija (Theory of Planned Behavior), kurioje apjungiami individualūs bei aplinkos veiksniai bei vertinamos jų sąsajos. Elgesys yra kognityviniu ir socialiniu procesų funkcija, kuri apsprendžia galimybes tą elgseną igyvendinti. Veiksmų ketinimai yra pirminis ir svarbiausias veiksmo atlikimo veiksnys. Ketinimai veikiami kelių veiksnių, tokių kaip išmokta elgesio kontrolè, požiūris ị elgesi, subjektyvios normos ir pati elgsena [17]. Atlikti tyrimai rodo, jog turintys didesnių ketinimų įsitraukti ị fizinio aktyvumo veiklas yra labiau linkę tai padaryti, lyginant su silpnesnių ketinimų grupe [2]. Manoma, kad ketinimus veikia socialiniai lūkesčiai, žmonių požiūris ir kontrolès suvokimas. Atliktas tyrimas vaikų grupejje parodè, jog palankų požiūrị i fizinị aktyvumą turintys vaikai linkę turèti stiprius ketinimus užsiimti fizine veikla palyginti su tais vaikais, kurie turi nepalankų požiūrị. Taip pat labai svarbus kitų asmenų požiūris ir paskatinimas užsiimti fizine veikla, t.y. kito socialiniai lūkesčiai. Tyrimas parodè, jog vaikai, kurie suvokè mokytojo lūkesčius užsiimti aktyvesne fizine veikla, buvo labiau linkę juos ir pateisinti. Tai reiškia, kitų socialiniai lūkesčiai gali sukurti ketinimą tapti fiziškai aktyviems. Galiausiai vaikai, kurie jautė kontroliuojant jų fizinį aktyvumą, linkę dažniau ìvardyti tvirtus fizinès veiklos ketinimus palyginti su vaikais, kurie patyrè silpnesnị kontrolès pojūtį [31].
Apsisprendimo teorija (Self-determination theory) yra sąlyginai nauja motyvacijos teorija, papildanti kitas motyvacines teorijas. Ji koncentruoja dèmesị ị vidinès ir išorinès motyvacijos santykị ir aiškina, kaip išorinis įsikišimas ir itaka veikia žmonių priimamus sprendimus [52]. R. Ryan ir E. Deci [43] išskiria skirtingus motyvacijos tipus priklausomai nuo atliekamų veiksmų priežasčių ir tikslų: vidinė ir išorine motyvacija bei atsiribojimas arba demotyvacija, kurią sąlygoja atliekamų veiksmų vertès nejautimas bei netikejjimas savo galimybèmis tuos veiksmus atlikti (pvz.: nusivylęs savo rezultatais sportininkas). E. Deci ir R. Ryan [13], priklausomai nuo asmens autonomijos laipsnio, išskiria keturis išorinès motyvacijos tipus: išorinio reguliavimo, introdukuoto, identifikuoto ir integruoto reguliavimo. Visi jie priklauso nuo aplinkos sąlygų, nuo kontroliuojančios asmens elgesi taikant apdovanojimus ir bausmes, iki palaikančios asmens savarankiškumą (integruoto reguliavimo aplinka). Taigi apsisprendimo teorijoje svarbiausias klausimas - ištirti tarpusavio skirtumus, susijusius su pagrindinių poreikių tenkinimu, kuri lemia skirtingos poreikius palaikančios aplinkos sąlygos [43]. Todèl apsisprendimo teorija skiria dviejų tipų aplinką. Teigiama, kad aplinka yra palaikanti autonomiją, kai tarpasmeninis asmenų, turinčių tam tikrą galią, (t. y. pedagogas, tèvai) bendravimo stilius atsižvelgia ị individo perspektyvą. Be to, aplinka palaiko savarankiškumą, kai galią turintys asmenys aiškiai paaiškina, kodèl atitinkamas individo elgesys yra svarbus. Toks paaiškinimas ir supratimas gali padèti suprasti kryptị ir sustiprinti kompetencijos jausmą, ką ir suteikia teigiamas grịžtamasis ryšys [43]. Galiausiai autonomiją palaikanti aplinka patenkina savarankiškumo poreikị, suteikiant galimybes rinktis per asmenini bendravimą naudojant neutralią kalbą (pvz., naudojami tokie veiksmažodžiai, kaip "galètum", o ne "privalètum") [14]. Suprantama, kad aplinka yra kontroliuojama, kai dviejų iš trijų svarbių veiksnių, sudarančių autonominę aplinką (pagrindimas, pasirinkimas ar perspektyvinis požiūris), nèra aplinkoje [14]. Tuo tarpu kontroliuojanti aplinka yra laikoma tada, kai galią turintys asmenys (mokytojai, tèvai) nesuteikia prasmingo pagrindimo (paaiškinimo), bendraudami naudoja spaudimą (pvz., vietoj „turètų” naudoja ,privalo”) ir (arba) verčia priimti jų požiūrị [14]. Taigi apsisprendimo teorija daro prielaidą, kad žmonès keičiasi priimant aplinkos iššūkius ir formuojant patirtị esant socialiniam palaikymui ir paramai. Tai reiškia, kad socialinis kontekstas gali paskatinti arba kurti barjerus žmogui tobulèti [44].

Studentų fizinio aktyvumo veiksniai. Apibendrinant aukščiau aptartas fizinį aktyvumą analizuojančias teorijas bei jų pagrindu atliktų tyrimų rezultatus išryškejjo, jog fizinis aktyvumas yra procesas ar veiksmų visuma, sąlygojamas kompleksinių prielaidų visumos. Viena vertus, motyvacija 
fiziniam aktyvumui atsiranda ir yra palaikoma vidinių asmens predispozicijų, tokių kaip nuostatos, asmeninis veiksmingumas, apsisprendimas, kas reiškia, jog fiziniu aktyvumu užsiimama su malonumu ir išgyvenamas pasitenkinimas [33]. Tačiau ypatingai svarbios tampa ir kontekstinès aplinkybès, galinčios vidini asmens nusiteikimą fizinio aktyvumo atžvilgiu keisti, t.y. skatinti arba slopinti. Tai ypač akcentuojama socialinès-kognityvinès, apsisprendimo bei planuojamo elgesio teorijų principinèse nuostatose. Jose pripažinimas ir parama socialinėje aplinkoje, t.y. šeimos, draugų, mokymosi/ studijų aplinkos veiksniai, sąveikaudami su asmens vidinemis nuostatomis, daro ittaką jauno asmens ketinimams ir nuostatoms užsiimti fizinio aktyvumo veiklomis bei naudos suvokimui $[43,16,17,36]$. C. Currie ir kt. [11] atskleidžia, jog šeima vaidina labai didelị vaidmeni paskatinant ar slopinant vaiko, o vèliau ir jauno suaugusiojo fizinį aktyvumą. Tai veikia per kultūrinius mechanizmus, tokius kaip fizinio aktyvumo tradicijos, laisvalaikio formos, susiformavę ìūdžiai,o ekonominis kapitalas neretai nulemia, kokia fizinio aktyvumo šaka gali (arba negali apskritai) užsiimti vaikas šeimoje [29]. Tyrimai rodo, jog ekonomiškai stipresnių šeimų vaikai yra fiziškai aktyvesni $[11,29]$. Tèvų parama buvo susijusi ir per teigiamą asociaciją su vaiko asmeninio efektyvumo suvokimu. R. Motl ir kt. [35] pažymi, jog asmeninis efektyvumas susijęs su didesniu savarankiškumu ir suvokiama nauda aktyviau isitraukti i fizinio aktyvumo veiklas. Kad jaunas žmogus atskleistu savo potencialą, jis turi būti pripažintas ir skatinamas socialinèje aplinkoje. Todèl bendraamžių įtaka gali būti skatinanti ịsitraukti arba slopinanti fizinį aktyvumą. Jei jaunas asmuo priklausė fiziškai aktyviai grupei, tai jis ir pats labiau ịsitraukia ị ivairias sportines veiklas, ir atvirkščiai $[3,10,16]$.

Empiriniai tyrimai rodo, kad svarbus veiksnys, skatinantis jaunus žmones dalyvauti fizinèje veikloje, yra sveikata [9], kūno įvaizdžio tobulinimas [8], psichologinès būsenos pagerinimas [1]. Teigiama, jog vidiniai motyvai labiau veikia ịsitraukimą i fizinį aktyvumą, tačiau motyvai ne visuomet gali būti aiškiai priskirti išoriniams ar vidiniams [48]. Kaip antai, sveikatos motyvas užsiimti fizine veikla gali atspindèti sveikatai kylančią riziką arba būti susijęs su patrauklia išvaizda [51]. Dažnai jaunimas užsiimti fiziniu aktyvumu stumiamas išorinių faktorių, tokių kaip pripažinimas, apdovanojimai, konkurencija, vertinimai ar nuomonè apie juos. Tokie faktoriai dažnai žmones motyvuoja priklausomai nuo jų interesų (1 lentelè).

Taigi vidinè motyvacija, nors ir ịvardijama kaip prigimtinis reiškinys, yra reguliuojama ne vien paties individo, bet, E. Deci ir R. Ryan [43] teigimu, daugiau priklauso nuo išorinių faktorių, aplinkos, ị kurią jis patenka. Kalbant apie studentų populiacijos fizinio aktyvumo sąlygas, reikšmingi tampa specifiniai su studijomis susiję kontekstiniai veiksniai ir ịvykiai. Studijos lemia gyvenimo sąlygų pasikeitimus. Dažnai jaunimas palieka tėvų namus, pradeda labiau savarankišką gyvenimo etapą, pasikeičia aplinka, kinta socialinis tinklas,

1 lentelè. Studentų fizinio aktyvumo motyvaciją sąlygojančių veiksnių sistema.

\begin{tabular}{|c|c|}
\hline Veiksnių grupès & Veiksniai \\
\hline Individualūs veiksniai & Amžius, lytis, išsilavinimas, etniškumas \\
\hline Gyvenamoji vieta & Miestas/kaimas \\
\hline $\begin{array}{l}\text { Gyvenamos vietos inf- } \\
\text { rastruktūra }\end{array}$ & $\begin{array}{l}\text { Ar gyvenama aplinka palanki fiziniam aktyvumui (parkai, } \\
\text { miškai, rekreacinės zonos, dviračių važiavimo takai, sporto } \\
\text { aikštelès ir pan.) }\end{array}$ \\
\hline Šeimos tradicijos & $\begin{array}{l}\text { Užsièmimas fizine veikla su tèvais, fizinės veiklos formos } \\
\text { su tėvais, fizinio aktyvumo kultūra ir tradicijos šeimoje, } \\
\text { skatinimas ir palaikymas }\end{array}$ \\
\hline Gyvenimo pokyčiai & $\begin{array}{l}\text { Apsigyvenimas savarankiškai, kaiminystè, dienotvarkès } \\
\text { pokyčiai, laiko pakankamumas fizinei veiklai }\end{array}$ \\
\hline Socialinis tinklas & $\begin{array}{l}\text { Draugų fizinio aktyvumo lygis, palaikymas, laisvalaikio } \\
\text { formos }\end{array}$ \\
\hline $\begin{array}{l}\text { Universiteto aplinka ir } \\
\text { sąlygos }\end{array}$ & $\begin{array}{l}\text { Studijų krūvis, studijų turinys (sveikatos temos), kultivuoja- } \\
\text { mos sporto rūšys, sporto salè, puoselèjamos fizinès veiklos } \\
\text { tradicijos }\end{array}$ \\
\hline $\begin{array}{l}\text { Pasitenkinimas spor- } \\
\text { tine veikla }\end{array}$ & $\begin{array}{l}\text { Patinka/nepatinka, teikia/neteikia džiaugsmo, galimybė } \\
\text { užsiimti mėgiama fizine veikla, naudos suvokimas }\end{array}$ \\
\hline $\begin{array}{l}\text { Psichologinès būsenos } \\
\text { gerinimas }\end{array}$ & $\begin{array}{l}\text { Streso mažinimas, stabilumas, nuotaikos gerinimas, } \\
\text { džiaugsmo išgyvenimas }\end{array}$ \\
\hline Socializacija & $\begin{array}{l}\text { Jaučiasi priklausantis grupei, vienijanti draugus veikla, } \\
\text { ịsitraukimas ị judejjiimus, galimybė pažinti kitus žmones, } \\
\text { kultūras, keliauti, dalyvauti, pripažinimas, parama, kitų } \\
\text { asmenų/bendruomenès socialinių lūkesčių patenkinimas }\end{array}$ \\
\hline Savęs tobulinimas & Orientacija ị tikslą, valios stiprinimas, progreso vertinimas \\
\hline Sveikata ir grožis & $\begin{array}{l}\text { Sveikatos stiprinimas, sveikatos problemų sprendimas, } \\
\text { atstatymas, kūno tobulinimas, svorio kontrolè, svorio ko- } \\
\text { regavimas, jèga, konkurencija }\end{array}$ \\
\hline Nuostatos ir požiūriai & $\begin{array}{l}\text { Fizinias aktyvumas svarbus/nesvarbus, judejjimas vertybè, } \\
\text { issitikinimai ir tikejjimas, jog asmuo gali užsiimti atitinkama } \\
\text { veikla }\end{array}$ \\
\hline Ekonominiai veiksniai & $\begin{array}{l}\text { Materialinių resursų pakankamumas, šeimos parama, sa- } \\
\text { varankiškos pajamos, naudojimasis automobiliu, dviračių, } \\
\text { spec. sportine įranga }\end{array}$ \\
\hline
\end{tabular}


dienotvarkè. Esami tyrimai atskleidžia nepakankamą studentų fizinio aktyvumo lygi. Kaip pagrindines nepakankamo fizinio aktyvumo priežastis jie nurodo laiko trūkumą, didelị studijų krūvị, nenorą užsiimti fizine veikla, palaikymo trūkumą, universitetinès aplinkos ir kultūros ypatumus [15,27]. Universitetinė aplinka labai reikšminga studentų fiziniam aktyvumui. Universiteto sporto ir kūno kultūros tradicijos, bendruomenès ịsitraukimas ir palaikymas, infrastruktūros fiziniam aktyvumui plètojimas, remiamos sporto šakos, sporto inventorius ir netgi su sveikata susijęs studijų turinys, kaip, pvz., ị studijų tinkleli įtrauktas su sveikata susiję modulis, kuria arba skatinančią fizinį aktyvumą aplinką, arba tampa kliūtimi tuo užsiimti (1 pav.) $[15,30]$.

Sudarytas studentų fizinio aktyvumo veiksnių modelis remiasi vidinès ir išorinès motyvacijos samprata, kuri atsispindi praktiškai visose ankstesniame skyriuje nagrinètose teorijose. Modelio šerdis yra asmens vidinès motyvacijos komponentai, kurie iš esmès reiškia, jog asmuo fiziniu aktyvumu užsiima su džiaugsmu, tai teikia jam vidini pasitenkinimą [33]. Svarbi sąlyga - kad individas suvoktų naudą, savo veiksmų sąmoningumą, o fizinè veikla būtų grindžiama tikèjimu, jog asmuo gali atlikti norimus veiksmus ir gali patirti sèkmę [35]. Tuo tarpu išorinė motyvacija susijusi su asmens veikla, kurią jis atlieka tikèdamasis gauti papildomą rezultatą, t.y. apdovanojimą, pripažinimą, palaikymą, išvengti bausmés ir pan. [43]. Remiantis apsisprendimo bei socialinio išmokimo teorijomis, išorinès fizinio aktyvumo priežastys gali sustiprinti arba slopinti vidinès motyvacijos sąlygas. Jaunam asmeniui ryšiai arba santykiai padeda funkcionuoti ir tobulèti sociume ar grupejje, todèl pripažinimas ir palaikymas artimoje aplinkoje (šeima, draugai, mokytojai, dėstytojai, bendruomenè) vaidina labai svarbų vaidmeni per kultūrinius instrumentus (tradicijos, palaikantys santykiai, susiformavę elgesio modeliai ir pan.) $[3,10,11,16]$. Svarbūs tampa su studijomis susiję kontekstiniai veiksniai ir ịvykiai, tokie kaip socialinio tinklo, gyvenimo sąlygų pokyčiai, aukštojoje mokykloje puoselejamos fizinio aktyvumo tradicijos, sporto inventorius

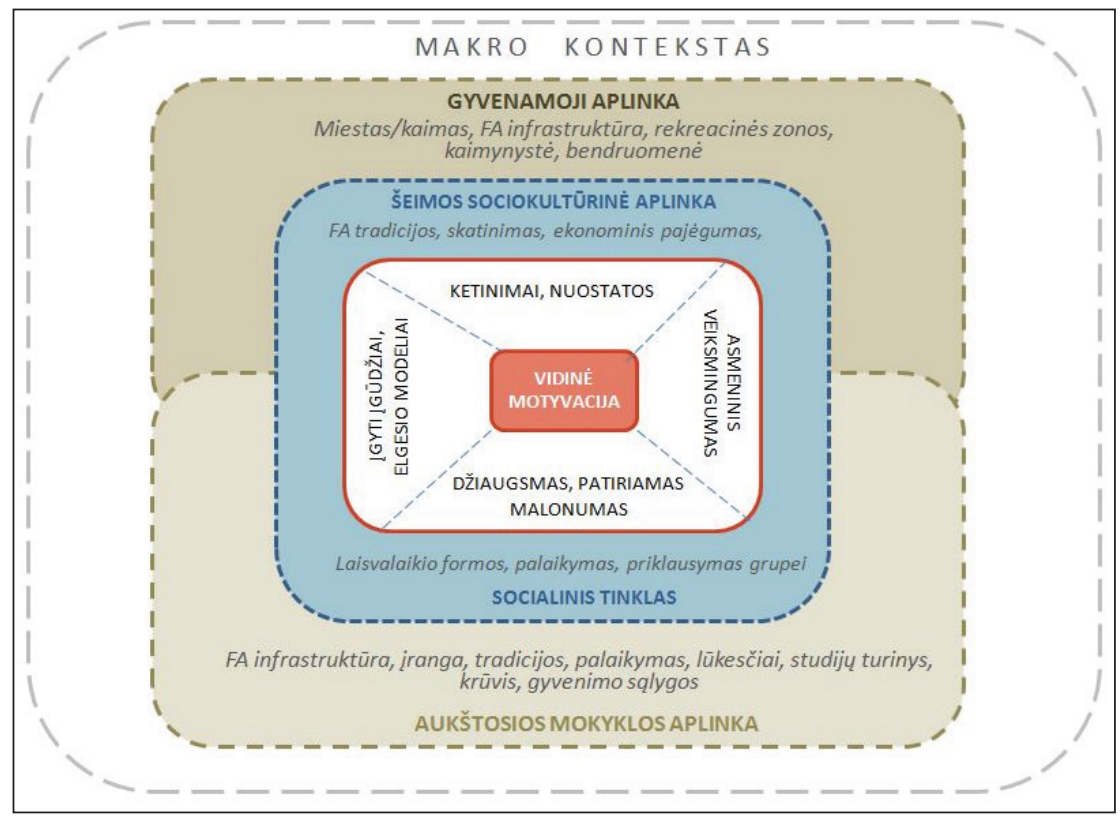

1 pav. Teorinis studentų fizinị aktyvumą sąlygojančių veiksnių modelis. ir infrastruktūra, studijų krūvis ir pan. [15]. Modelyje išryškinta vidinių ir išorinių motyvacijos veiksnių takoskyra yra sąlyginè, suvokiant, jog vieni be kitų iš esmès neegzistuoja/neveikia ir gali skatinti arba slopinti fizinio aktyvumo ketinimus.

\section{Išvados}

1. Išanalizuoti teoriniai požiūriai, taikomi paaiškinti jaunimo fizinio aktyvumo reiškini, yra ekologinis modelis, socialinis ekologinis modelis, socialinè kognityvinè teorija, Penderio sveikatos skatinimo modelis, planuojamo elgesio teorija, asmeninio veiksmingumo ir asmeninès schemos teorija, apsisprendimo teorija. Jie atskleide, jog fizinis aktyvumas yra sąlygojamas tiek vidinių asmens predispozicijų, tiek artimosios socialinès aplinkos bei kontekstinių kultūrinių, ekonominių, struktūrinių veiksnių visumos.

2. Apibendrinant studentų fizini aktyvumą sąlygojančius veiksnius galima suskirstyti i penkias grupes: demografiniai ir biologiniai veiksniai; psichologiniai, kognityviniai ir emociniai veiksniai; elgesio atributai ir igūdžiu veiksniai; socialiniai ir kultūrinai faktoriai; fiziniai aplinkos veiksniai.

3. Fizinis aktyvumas yra procesas ar veiksmų visuma, sąlygojamas kompleksinių prielaidų visumos. Motyvacija fiziniam aktyvumui atsiranda ir yra palaikoma ne vien vidinių asmens predispozicijų, tokių kaip nuostatos, asmeninis veiksmingumas, apsisprendimas, tačiau ypač svarbios tampa ir kontekstinès aplinkybės, galinčios vidinị asmens nusiteikimą fizinio aktyvumo atžvilgiu keisti, t.y. skatinti arba slopinti. Svarbus tampa socialinis palaikymas, t.y. šeimos, draugų, mokymosi/studijų aplinkos veiksniai, sąveikaudami su asmens vidinèmis nuostatomis, veikia jauno asmens ketinimus ir nuostatas fizinio aktyvumo veikloms bei naudos suvokimą. Reikšmingi tampa specifiniai su studijomis susiję kontekstiniai veiksniai 
ir ịvykiai, tokie kaip gyvenimo sąlygų, draugu pasikeitimas, aukštojoje mokykloje puoselèjamos fizinio aktyvumo tradicijos, remiamos sporto šakos, sporto inventorius, studiju krūvis, pasikeitusi dienotvarké, netgi studijų turinys.

\section{Literatūra}

1. Aaltonen S, Kujala UM, Kaprio J. Factors behind leisure-time physical activity behavior based on Finnish twin studies: the role of genetic and environmental influences and the role of motives. BioMed Research International, 2014;2014:931820. https://doi.org/10.1155/2014/931820

2. Ajzen I. The theory of planned behaviour. Organizational Behavior and the Human Decision Process 1991; 50:179-211

3. Ammouri AA, Kaur H, Neuberger GB, Gajewski B, Choi WS. Correlates of exercise participation in adolescents. Public Health Nursing 2007; 24:111-120. https://doi.org/10.1111/j.1525-1446.2007.00615.x

4. André N, Dishman R. Evidence for the construct validity of self-motivation as a correlate of exercise adherence in French older adults. Journal of Aging and Physical Activity 2012; 20(2):231-245.

https://doi.org/10.1123/japa.20.2.231

5. Bergier J, Bergier B, Tsos A. Variations in physical activity of male and female students from the Ukraine in health-promoting life style. Annals of Agricultural and Environmental Medicine 2017; 24(2):217-221.

6. Booth FW, Roberts CK, Laye MJ. Lack of exercise is a major cause of chronic diseases. Compr Physiol. 2012; 2(2):11431211.

https://doi.org/10.1002/cphy.c110025

7. Borsari B, Murphy JG, Barnett NP. Predictors of alcohol use during the first year of college: Implications for prevention. Addictive Behaviours 2007; 32(10):2062-2086.

https://doi.org/10.1016/j.addbeh.2007.01.017

8. Brudzynski LR, Ebben W. Body image as a motivator and barrier to exercise participation. International Journal of Exercise Science 2010;3(1):14-24.

9. Caglar E, Canlan Y, Demir M. Recreational exercise motives of adolescents and young adults. Journal of Human Kinetics 2009; 22:83-89.

https://doi.org/10.2478/v10078-009-0027-0

10. Chang MC. Behavioral and sociocultural influences on PA among Asian-American youth. Unpublished doctoral dissertation, University of Michigan, Ann Arbor, Michigan, USA, 2004.

11. Currie C, Zanotti C, Morgan A, Currie D, de Looze M, Roberts $\mathrm{Ch}$. Social determinants of health and well-being among young people. Health Behaviour in Scool - Aged Children (HBSC) Study: International Report from the 2009 / 2010 Survey. World Health Organization Regional Office for Europe, 2012.

12. De Bruijn GJ, Kremers SP, Lensvelt-Mulders G, de Vries H, van Mechelen W, Brug J. Modeling individual and physical environmental factors with adolescent physical activity. Am J Prev Med 2006;30(6):507-512.

13. Deci EL, Ryan RM. Intrinsic motivation and self-determination in human behavior.New York: Plenum, 1985

14. Deci EL, Eghrari H, Patrick BC, Leone DR. Facilitating internalization: the self-determination theory perspective. Journal of Personality 1994;62:119-142. https://doi.org/10.1111/j.1467-6494.1994.tb00797.x

15. Deliens T, Deforche B, De Bourdeaudhuij I, Clarys P. Determinants of physical activity and sedentary behaviour in university students: a qualitative study using focus group discussions. BMC Public Health 2015; 15:201.

https://doi.org/10.1186/s12889-015-1553-4

16. Dowda M, Dishman RK, Pfeiffer KA, Pate RR. Family support for physical activity in girls from 8th to 12th grade in South Carolina. Preventive Medicine 2007; 44:153-159.

https://doi.org/10.1016/j.ypmed.2006.10.001

17. Fishbein M, Ajzen I. Predicting and changing behavior: The reasoned action approach. New York: Psychology Press, 2010

18. Glanz K, Rimer BK, Viswanath K. Health Behaviour: Theory, Research, and Practice, 5th Edition. Jossey \& Bass Public Health 2015:512

19. Haase A, Steptoe A, Sallis J, Wardle J. Leisure time physical activity in university students from 23 countries: associations with health beliefs, risk awareness, and national economic development. Preventive Medicine 2004; 39(1):182-190. https://doi.org/10.1016/j.ypmed.2004.01.028

20. Hagger M, Chatzisarantis N.Self-determination theory and the psychology of exercise. International Review of Sport and Exercise Psychology1 2008;(1):79-103.

21. Hallal PC, Andersen LB, Bull FC, Guthold R, Haskell W, Ekelund U. Global physical activity levels: surveillance progress, pitfalls, and prospects.Lancet 2012; 380(9838):247-257.

22. Humbert ML, Chad KE, Spink KS, Muhajarine N, Anderson $\mathrm{KD}$, Bruner MW. Factors that influence physical activity participation among high- and low-SES youth. Qualitative Health Research 2006; 16:467-483.

https://doi.org/10.1177/1049732305286051

23. Irwin JD. Prevalence of university students' sufficient physical activity: a systematic review. Perceptual and Motor Skills 2004; 98(3):927-943

https://doi.org/10.2466/pms.98.3.927-943

24. Kendzierski D. Self schema and exercise. Basic and Applied Social Psychology 1988; 9(1):45-49 https://doi.org/10.1207/s15324834basp0901_4

25. Khodaveisi M, Omidi A, Farokhi Sh, Soltanian AR. Dietary behavior status and its predictors based on the Pender's health promotion model constructs among overweight women. Int J Community Based Nurs Midwifery 2017; 5(2):165-174.

26. Knight J. Physical inactivity: associated diseases and disorders. 
Annals of Clinical and Laboratory Science 2012; 42(3):320-337.

27. Kwan MYW, Bray SR, Martin Ginis KA. Predicting physical activity to first year university: An application of the Theory of Planned Behavior. Journal of American College Health 2009;58:45-52.

28. Lee IM, Shiroma EJ, Lobelo F, Puska P, Blair SN, Katzmarzyk PT. Effect of physical inactivity on major noncommunicable diseases worldwide: an analysis of burden of disease and life expectancy.Lancet 2012; 380 (9838):219-229.

29. Logstein B, Blekesaune A, Almas R. Physical activity among Norwegian adolescents - a multilevel analysis of how place of residence is associated with health behaviour: the YoungHUNT study. International Journal for Equity in Health 2013;12:56

https://doi.org/10.1186/1475-9276-12-56

30. Lopez MG, Gallegos AG, ExtremeraAB. Perceived barriers by university students in the practice of physical activities. Journal of Sports Science and Medicine 2010;9:374-381

31. Martin JJ, Kulinna P, McCaughtry N, Cothran D, Dak J, Fahoome G. The theory of planned behavior: Predicting physical activity and cardiorespiratory fitness in African American children. Journal of Sport and Exercise Psychology2005; 27(4):456-469.

32. McLeroy KR, Bibeau D, Steckler A, Glanz K.An ecological perspective on health promotion programs. Health Educ Q. 1988 Winter; 15(4):351-77.

33. Molanorouzi K, Khoo S, Morris T. Motives for adult participation in physical activity: type of activity, age, and gender. BMC Public Health 2015;15(660).

34. Moore L, de Silva-Sanigorski A, Moore SN. A socioecological perspective on behavioural interventions to influence food choice in schools: alternative, complementary or synergistic? Public Health Nutr 2013 Jun;16(6):1000-1005.

35. Motl RW, McAuley E, Snook EM. Physical activity and multiple sclerosis: a metaanalysis. Multiple Sclerosis Journal 2005; 11(4):459-63.

https://doi.org/10.1191/1352458505ms1188oa

36. Neumark-Sztainer D, Story M, Hannan PJ, Tharp T, Rex J. Factors associated with changes in physical activity. A cohort study of inactive adolescent girls.Archives of Pediatric and Adolescent Medicine 2003; 157:803-810.

https://doi.org/10.1001/archpedi.157.8.803

37. Pedišić Ž, Rakovac M, Bennie J, Jurakić D, Bauman AE. Levels and correlates of domain specific physical activity in university students: cross-sectional findings from Croatia. Kinesiology 2014; 46(1):12-22

38. Pender NJ, Murdaugh CL, Parsons MA. Health Promotion in Nursing Practice. 6th ed. Boston, MA: Pearson; 2010.

39. Pender NJ. Heath Promotion Model Manual. Michigan, United State: University of Michigan; 2011

40. Petosa R, Suminski R, Horts B. Predicting vigorous physical activity using social cognitive theory. American Journal Of
Health Behavior 2003; 27(4): 301-310.

41. Pis M. Physical activity social support, selfefficacy, and selfdefinition in adolescents: A correlational cross-sectional comparative study. Dissertation, University of Michigan, 2006.

42. Richard L, Potvin L, Kishchuk N, Prlic H, Green LW. Assessment of the integration of the ecological approach in health promotion programs. Am J Health Promot 1996 Mar-Apr; 10(4):318-28.

43. Ryan RM, Deci EL. Instrinsic and extrinsic motivations: Classic definitions and new directions. Contemeporary Educational Psychology 2000; 25:54-67.

https://doi.org/10.1006/ceps.1999.1020

44. Schunk DH, Usher EL. Social cognitive theory and motivation. In R. M. Ryan (Ed.), Oxford library of psychology.The Oxford handbook of human motivation2012:13-27. New York, NY, US: Oxford University Press.

45. Seefeldt V, Malina RM, Clark MA.Factors affecting levels of physical activity in adults. Sports Med 2002; 32(3):143-68.

https://doi.org/10.2165/00007256-200232030-00001

46. Shani D, Nimbalkar A, Phatak A, Nimbalkar S. Training in dietary practices and physical activity to improve health among South Asian medical students. Advances in Preventive Medicine, 2014.

47. Sherrick-Escamilla S.Factors affecting selfreported physical activity in children aged 10-12. Unpublished doctoral dissertation, Wayne State University, Detroit, Michigan, USA, 2007.

48. Sibley BA, Hancock L, Bergman SM. University students' exercise behavioural regulation, motives, and physical fitness. Perceptual \& Motor Skills: Exercise \& Sport 2013; 116(1):322-339.

49. Sisson SB, Katzmarzik PT. International prevalence of physical activity in youth and adults.Obesity Reviews 2008;9(6):606614.

https://doi.org/10.1111/j.1467-789X.2008.00506.x

50. Stokols D. Translating social ecological theory into guidelines for community health promotion. American Journal of Health Promotion: AJHP 1996;10(4):282-98.

51. Teixeira M, Coledam DH, Junior RP, Greca J, Arruda GA, Oliveira ARD. Physical exercise practice and associated factors among undergraduate students from a southern region of Brazil. Human Movement 2016; 17(4), 229-236.

52. Titenytė - Mackonienè A. Mokyklų vadovų ir mokytojų motyvavimo strategijos kaip mokinių vidinès mokymosi motyvacijos veiksniai. Vilnius. VPU leidykla, 2005.

53. Vella-Zarb RA, Elgar FJ. The 'freshman 5': a metaanalysis of weight gain in the freshman year of college. Journal of American College Health 2009; 58(2):161-166. https://doi.org/10.1080/07448480903221392

54. Wu TY, Pender N. Determinants of physical activity among Taiwanese adolescents: as application of the health promotion model. Res Nurs Health 2003; 25:25-36. 


\section{FACTORS OF STUDENTS PHYSICAL ACTIVITY: A THEORETICAL FRAMEWORK D.Gužauskas, I.Mikutavičienė}

Key words: motivation, physical activity, factors of physical activity.

Sumarry

This article examines theoretical aspects of student physical activity. Irwin (2004), summarizing the study of physical activity in students in 27 different countries, notes that between $30 \%$ and $60 \%$ the students' physical activity did not meet the recommended rates and varied according to the country. Student populations are characterized by a certain specificity - a new stage of life begins, independence increases, parents change, place of residence, circle of friends, changed circumstances require new time planning skills, responsibility, changing agenda, increasing mental workload, increasing physically passive time spent on computer, studying, performing tasks. Changes in the environment can lead to the decreased physical activity.Although there is a lot of research in this area, there is a lack of a systematic, integrated approach to physical activity conditions, studies reflect one or several aspects of physical activity. Therefore, in order to increase the level of physical activity of students, it is first necessary to understand the phenomenon of physical activity and its components by reviewing various theoretical perspectives. The research problem is formulated on the question: What factors influence physical activity in the student population? The purpose of this presentation is to provide a theoretical framework explaining the system of factors influencing students" physical activity. Motivation for physical activity was considered from theoretical perspectives such as Social Cognitive Theory, Pender's Health Promotion Model, SelfEfficiency and Self-Structuring Theory, Ecological Model and So- cial Ecological Model, Theory of Planned Behavior, Self-Determination Theory.

The theoretical analysis have revealed that physical activity is conditioned both in terms of the internal predispositions of the individual, of the near social environment and of the contextual cultural, economic, structural factors.In summary, the factors influencing students' physical activity can be divided into five groups: demographic and biological factors; psychological, cognitive and emotional factors; attributes of behavior and skills factors; social and cultural factors; physical environmental factors.Physical activity is a process or a set of actions due to the complexity of complex assumptions. Motivation for physical activity arises and are not supported only by internal personal predispositions, such as provisions, personal effectiveness, self-determination, but also of particular importance are contextual circumstances that can change the inner person's mood towards physical activity, i.e. encourage or inhibit. Social support is becoming important, i.e. family, friends, learning / study environment factors, interacting with the person's internal attitudes, affects the intentions and provisions of the young person for activities of physical activity and the perception of the benefit. Significant contextual factors and events related to studies, such as the changing of living conditions, friends, traditions of physical activity fostered by the higher school, support sports, sports equipment, study load, changed agenda, even the content of studies, are becoming significant.

Correspondance to: inga7239@gmail.com

Gauta 2018-12-06 